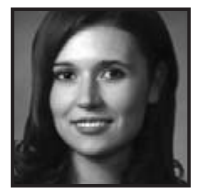

\title{
How Science Clubs Can Support Girls' Interest in Science
}

\author{
Larissa Vingilis-Jaremko
}

\section{ABSTRACT}

Enter any classroom across Canada, ask children to describe a scientist, and you will likely hear about brilliant, but crazy old men in lab coats and goggles doing dangerous experiments (the mad scientist). Stereotypes such as this, however, can affect an individual's likelihood to take science courses, and the attention he or she gives to the studies of the sciences. The Canadian Association for Girls in Science (CAGIS) attempts to break the scientist stereotype, and to facilitate interest and confidence in science, technology, engineering, and mathematics (STEM) by holding regular events with fun, hands-on activities led by women and men in STEM-related fields.

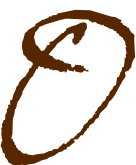

ne Saturday afternoon, Alison and Sarah were faced with a puzzle: they had a lemon battery in front of them connected to a small, red LED that would not glow. They were learning about electricity at a monthly event of the Canadian Association for Girls in Science (CAGIS). The girls checked their battery; they had inserted a penny, their positive terminal, into one end of the lemon, and a nail, their negative terminal, to the other end of the lemon. Both of their small jumper cables were correctly connected to the input and output leads of the LED. They looked around at the other girls in the room: all were engrossed in their batteries, double-checking connections, and trying other LEDs to find one that would glow. Ayesha, the young electrician running the event leaned between them, "maybe you don't have enough voltage in your lemon." The two girls looked at each other, puzzled. Alison looked back at the other girls fiddling with their lemon batteries. Suddenly, it came to her: if one lemon doesn't have enough voltage, what about two 
lemons!? She and Sarah grouped with the girls beside them, connecting penny to nail, positive to negative. They connected their two lemons to the LED and saw a faint flicker. Minutes later, the room was abuzz with excitement as the entire room of girls worked together, applying what they had learned to connect all of their lemons together in a series circuit. They waited in eager anticipation as the last lemon was connected to the LED. Eureka! A bright red glow! The girls at this event not only learned about electricity, but they also understood it; they experienced the excitement of discovery, had fun, and made new friends!

The Canadian Association for Girls in Science (CAGIS) is a science club for girls aged 7-16 with several chapters across the country. Our mission is to promote, educate and support interest and confidence in science, technology, engineering and mathematics (STEM) among girls. Members meet monthly at the workplaces of women and men in STEM fields to get a "behind the scenes" view of science in action, and do fun hands-on activities. In warm and supportive small group environments with a high ratio of volunteers to members, girls explore a variety of STEM topics. Members are as likely to meet with a civil engineer to build and test model bridges as they are to meet with an artist to learn the chemistry of art restoration. As the understanding is in the doing, much of the time at each event is dedicated to handson activities, which helps the girls understand, builds their confidence, and creates positive associations with the sciences.

I founded CAGIS at age 9 when I noticed that the girls in my class hated science and mathematics. I was surprised to hear my friends describe the sciences as "difficult," "boring," and "more of a guy thing." I had a very different view. Through my mother, a research scientist, and my father, an engineer, I had met many STEM professionals of both genders, had visited science centres, and had done fun experiments and activities at home. I thought STEM was fun and interesting, and I wanted to be a scientist! Indeed, my observations as a child were a common phenomenon; children and adolescents of various ages have repeatedly been found to have stereotypic, often negative views of scientists (for a review, see Finson, 2002). These stereotypes typically portray old men wearing lab coats and glasses, doing dangerous experiments in a lab (Finson, 2002). There are additional beliefs that scientists like to work in seclusion, have limited social lives, and have IQs in the genius range (Finson, 2002). Needless to say, many children and adolescents have misconceptions of what scientists actually do, who scientists are, and what they are like.

Stereotyping of STEM as a male domain is pervasive. It can be seen: in the media (the "mad scientist" makes frequent appearances on kids' shows and cartoons); 
in the home (something as subtle as a mother voicing that she is not good at technology, and deferring to dad for help with the DVD provides an example to children); and within social groups and friends (what is "cool" or "geeky"). Accordingly, girls are exposed to few female role models engaged in STEM-related activities. It may be of interest to note that gender-role stereotyping occurs early in life. Children have clearly defined gender-role stereotypes of what is appropriate by age five (Eccles, 1994), and sex segregation in careers goals emerges before age five with boys exhibiting greater interests in STEM professions than do girls throughout their childhood and adolescence (Weisgram \& Bigler, 2006). Within mixed-gender classroom environments, boys often take the active roles during science experimentation, while girls take on more passive roles such as note taking (Kahle et al., 1993; Burkham et al., 1997). These roles tend to become consolidated throughout grade and high school, and confidence and interest in STEM declines among girls (Ware \& Lee, 1988; Miller et al., 2006).

Stereotypes can additionally affect an individual's attitudes, and even performance in a particular domain (Acker \& Oatley, 1993; Steele, 1997; Steele et al., 2002). An individual's perceptions of scientists, for example, may affect the attention he or she gives to his or her studies of the sciences (Finson, 2002). An individual's selfefficacy in a given field is linked to his or her likelihood to pursue a career in that field (O'Brien et al., 1999). Individuals who have negative views of the sciences, then, are unlikely to take science courses, and subsequently pursue scientific careers (Finson, 2002). This leads us to the expression of the problem: an under-representation of women in many areas of STEM. Although we have seen advances with more women entering scientific courses in universities in recent decades, many fields remain male dominated. While women's enrolment had risen to $58 \%$ of the Canadian undergraduate population in physical and life sciences in 2003, it was $25.3 \%$ in mathematics, computer, and information technologies (CAUT, 2008). In engineering, Canadian undergraduate enrolment increased throughout the 1990s from $16.1 \%$ to $20.6 \%$ female in 2001, but it has steadily declined since then, to $17.1 \%$ female representation in 2008 (Engineers Canada, 2009). According to the 2006 Canadian Census, the percentage of women in the workforce in a variety of STEM fields including physical sciences, computers and information technology, technical occupations, and engineering ranged from $12.2 \%$ in engineering to $36.7 \%$ in the life sciences (CCWESTT, 2008). Women remain under-represented in many STEM fields.

In the current era of globalization, however, Canada must have a strong and sustainable knowledge-based economy. As reported at the Fifth Canadian Conference of Women in Engineering, Science, and Technology (1992), “Canada needs 
an educated workforce, particularly a workforce that is trained in the sciences, engineering, technology and trades. Half of all Canadians are women: ergo what Canada needs are more trained women in these industries."

Despite the under-representation of women in STEM fields, it is possible to promote girls' interest and achievement in STEM. We can do this in a variety of ways that work to break down stereotypes, provide social supports, change learning environments, increase exposure to STEM fields and hands-on activities, and increase exposure to female role models. For example, girls generally have less peer support for their STEM interests and activities than do boys (Brickhouse et al., 2000; Stake \& Nickens, 2005). However, in enrichment classes where peer relationships were encouraged, students reported having positive STEM peer relationships, and had more positive expectations of the possible personal self as a scientist (Stake \& Nickens, 2005). Changes in learning environments can also promote and support girls' interest in STEM. Girls like to learn in cooperative and supportive small group environments that encourage peer engagement (Brickhouse et al., 2000). Facilitating these types of environments can help to develop girls' interest and confidence in STEM. As boys often dominate science classes and activities (Schacter, 1998), one way to facilitate these types of environments is to provide single gender learning opportunities in STEM. Several studies have additionally found that girls are motivated by hands-on activities (Lee \& Burkam, 1996; Burkham et al., 1997; Brotman \& Moore, 2008). Lee and Burkam (1996) recommended that parents encourage girls to participate in science clubs and fairs because they responded well to the cooperative, small group environments. Finally, increasing exposure to female role models in STEM fields can improve attitudes towards scientists and can decrease stereotypical descriptions among elementary school students (Finson, 2002).

A variety of interventions can be effective in breaking stereotypes of the sciences, and increasing girls' interest in STEM fields. CAGIS attempts to use all of the methods listed above to encourage girls' interest and confidence in STEM. At our regular chapter events, members have the opportunity to meet other girls who are similarly exploring the sciences, which facilitates positive peer relationships. We provide supportive, small group learning environments that encourage interaction and peer engagement. Our events are full of fun, hands-on activities, which enhance learning, and build positive associations with STEM. Finally, our girls are exposed to many female role models in STEM, as many of our chapter volunteers are science and engineering students, as well as other members of the community. Additionally, many of the presenters and hosts of our regular events are women in STEM fields. Our girls, thus, have exposure to a wide variety of female role models in many areas of STEM. 
I am very proud to report that many of our past members have emailed us to let us know how CAGIS had a positive impact on their lives, and to inform us that they are now studying engineering, biochemistry, medicine, and physics, and trades such as welding (to name a few). Nothing is more rewarding than to see some shy, quiet CAGIS member come to life and become excited by the fun and discovery side of science. My hope is that CAGIS will give girls the confidence, the skills, and the knowledge to feel comfortable with science, technology, engineering and mathematics, and pursue their interests, whatever they may be.

\section{References}

Acker, S., \& Oatley, K. (1993). Gender issues in education for science and technology: Current situation and prospects for change. Canadian Journal of Education, 18(3), 255-272.

Brickhouse, N. W., Lowery, R., \& Schultz, K. (2000). What kind of a girl does science? The construction of school science identities. Journal of Research in Science Teaching, 37(5) 441-458.

Brotman, J.S., \& Moore, F.M. (2008). Girls and science: A review of four themes in the science education literature. Journal of Research in Science Teaching, 45(9), 971-1002.

Burkham, D., Lee, V.E., \& Smerdon, B.A. (1997). Gender and science learning early in high school: Subject matter and laboratory experiences. American Educational Journal, 34(2) 297-331.

Canadian Association of University Teachers (2008). Women's University Enrolments Trends by Level of Study and Discipline, 1992-2003. Retrieved May 16, 2010, from http://www.caut.ca/uploads/EquityRevie w3-en.pdf

Canadian Coalition of Women in Science, Engineering, Trades, and Technology (2008). Canadian Census, 2006. Retrieved May 16, 2010, from http://www. ccwestt.org/Statistics/tabid/59/ctl/Detail/ $\mathrm{mid} / 461 / \mathrm{xmid} / 146 / \mathrm{xmfid} / 11 /$ Default.aspx
Canadian Conference of Women in Science, Engineering and Technology (1993). Report of the Fifth Canadian Conference of Women in Engineering, Science and Technology. CAWIS-WISE, Toronto, Ontario.

Eccles, J. (1994). Understanding women's educational and occupational choices. Psychology of Women Quarterly, 18, 595-609.

Engineers Canada (2009). Canadian Engineers for Tomorrow: Trends in Engineering Enrolment and Degrees Awarded 20042008. Retrieved May 16, 2010, from http://www.engineerscanada.ca/files/w_ report_enrolment_eng.pdf

Finson, K.D. (2002). Drawing a scientist: What we do and do not know after fifty years of drawings. School Science and Mathematics, 102(7), 335-345.

Kahle, J.B., Parker, L.H., Rennie, L.J., \& Riley, D. (1993). Gender differences in science education: Building a model. Educational Psychologist, 28, 379-404.

Lee, V.E., \& Burkham, D.T. (1996). Gender differences in middle grade science achievement: Subject domain, ability level, and course emphasis. Science and Education, 80(6) 613-650.

Miller, P.H., Slawinski Blessing, J., \& Schwartz, S. (2006). Gender differences in high-school students' views about science. International Journal of Science Education, 28(4), 363-381. 
O'Brien, V., Kopala, M., \& Martinez-Pons, M. (1999). Mathematics self-efficacy, ethnic identity, gender, and career interests related to mathematics and science. The Journal of Educational Research, 92(4), 231-235.

Schacter, H. (1998). Equality quest: Is the classroom as gender-divided as ever? Canadian Family September, 34-44.

Stake, J.E., \& Nickens, S.D. (2005). Adolescent girls' and boys' science peer relationships and perceptions of the possible self as scientist. Sex Roles, 52, 1-11.

Steele, C.M. (1997). A threat in the air. How stereotypes shape intellectual identity and performance. American Psychologist, 52(6), 613-629.
Steele, J., James, J.B., \& Chait Barnett, R. (2002). Learning in a man's world: Examining the perceptions of undergraduate women in male-dominated academic areas. Psychology of Women Quarterly, 26, 46-50.

Ware, N.C., \& Lee, V.E. (1988). Sex differences in choice of college science majors. American Educational Research Journal, 25(4) 593-614.

Weisgram, E.S., \& Bigler, R. S. (2006). Girls in science careers: The role of altruistic values and attitudes about scientific tasks. J. of Applied Developmental Psychology, 27, 326-348.

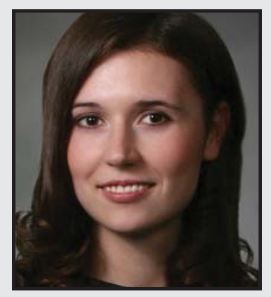

Larissa Vingilis-Jaremko is founder and president of the Canadian Association for Girls In Science (CAGIS), a notfor-profit science club for girls aged 7-16. In a girls-only, supportive environment, CAGIS members explore science, technology, engineering, and mathematics topics with women and men in those fields. With lots of time devoted to fun, hands-on activities, the ultimate goal is to make girls comfortable with STEM and to break down fears and gender stereotypes. Larissa holds an Honours BSc from the University of Toronto, and is a PhD student in the Department of Psychology, Neuroscience, and Behaviour at McMaster University.

Larissa was named in 2006 as one of Canada's Top 100 Most Powerful Women (in the Globe and Mail by the Women's Executive Network), and she received the highly competitive TD Canada Trust Scholarship for Outstanding Community Leadership. She has participated and advised science roundtables such as the Canadian Space Agency Roundtable and the NSERC Science Colloquium. 